\title{
sciendo
}

\section{Considerations on penalty clauses: regulation and enforceability}

\author{
Roxana Maria CHIRIEAC \\ Bucharest University of Economic Studies, Bucharest, Romania \\ roxana.chirieac@gmail.com
}

\begin{abstract}
Penalty clauses are regulated in the Romanian law through the provisions of the civil Code. These types of clauses are frequently inserted in commercial contracts in order to ensure that all contracting parties will respect their obligations, or will pay the pre-evaluated damages considered by the parties at the conclusion of the contract. As opposed to the common-law regulations, the continental law systems allow and support such clauses, mainly because of the liberty of the parties when concluding a contract; nevertheless, our legislation, as other European legislations allow the mutability of penalty clauses, when they are deemed excessive.

In the present study, we aimed to analyze the nature of the penalty clause in the Romanian regulations, as well as study their applicability in commercial contracts, especially when inserted in contracts that are concluded over longer periods of time for the supply of services. We aim to understand if such a clause might be deemed inapplicable if one of the parties decides upon the termination of the contract ahead of term or simply wants to reduce the clause in order to pay a lesser penalty.

The legislation states that such clauses may be amended by the court when part of the principal obligation was partly upheld by the party and its execution has profited the creditor, or when the penalty is "manifestly excessive" as opposed to the prejudice that could have been foreseen by the parties at the conclusion of the contract. Based on the current state of legislation, while analyzing doctrine and jurisprudence, we aim to underline what a manifestly excessive penalty should be.
\end{abstract}

Keywords: penalty clause, commercial contracts, mutability, excessive, unfair terms.

\section{Introduction}

Any type of commercial contract, regardless if it is concluded between private parties, merchants or consumers, or between merchants and contracting authorities, assumes the concurrence of the will of the parties. This can be met either through negotiations or through the acceptance, without reserves, of an offer made by one of the parties.

In accordance with the provisions of the Romanian civil Code, the parties are free to conclude any type of contract and to determine their content, as long as they abide the limits imposed by the law, the public order and good morals (article 1169 of the civil Code). There is an obligation for the respect of good faith, provided in the following article that must be maintained even before the conclusion of the contract, in the negotiations phase and its conclusion, as well as throughout the execution of the contract.

As such, parties are free to stipulate any type of clause that they claim might ensure the respect of their contracts and could best represent their interests. A particular type of clause, the object of the present study is the penalty clause, regulated by the articles 1538-1543 of the Romanian civil Code. Through such clause parties can provide that if a contract is not executed or not executed in accordance to its provisions, the creditor of the obligation can request the payment of penalties.

It should be noted that in accordance with the regulations in force, the creditor has the right to the full reparation of the prejudice he suffers by the nonexecution of an obligation, this full remedial being comprised on one hand of the effective loss that the creditor suffered and on the 
other by the benefice that he was deprived of. One must note, when studying these provisions, that contractual clauses must not become abusive, in the sense that they must not be inequitable for the other party, offering the creditor the possibility to take advantage in an unjust matter of the fact of inexecution of the contractual provisions. The latter might constitute grounds for un unjust enrichment, as provided by the civil Code (article 1345) and thus affect the validity of the contract.

Given the recent political changes that have occurred in Romania during the past year, as well as press scandals that have recently made headlines, one must wonder about the applicability of a penalty clause within a commercial contract, especially if the said contract is concluded between a private company and a contracting authority, such as a district town hall. Taking into account the nature of the contract as well as the nature of the services provided within the said contract, we consider that the common regulations set out by the Civil code are applicable.

As doctrine has shown, the penalty clause has its origins in the Roman law, and was later developed in the French cannon law: as such, it has provided in different times for two main objectives - the first ensuring the execution of a contract and the second, the penalties that the non-complying party must pay, in order to repair the prejudice of the other parties (Ludușan, 2014, p. 94-95). Over time, it has evolved and is in present regulated by our civil Code not only to cover the prejudice for the non-execution of a contract, but also to cover the prejudice if the obligation is not fulfilled in accordance with the contractual terms. We concur with the opinion expressed in doctrine, that a penalty clause can also be provided if the contract is rescinded or terminated before the term stipulated by the parties (Angheni, 2016, p. 10). We consider that in order to fulfil a contract, taking into account the economic realities provided by the current market, one of the parties might have to invest or develop its infrastructure in order to comply and deliver merchandise or services in accordance to the parties' agreement; however, this investment or development might not be sustainable for the party if the contract is not carried out over a longer period of time. As such, if the contract can be terminated or rescinded without penalties by the other party, the first party who made the investments or developed its infrastructure in order to be able to deliver in accordance with the contractual provisions will be faced will loses, that couldn't have been foreseen at the conclusion of the contract. Moreover, one must take into account, that at the conclusion of the contract, each party takes into consideration several elements, among which we consider the duration of the contract; as such, if the duration would have been different, one of the parties might have not agreed to the conclusion of the contract in those terms, or at all.

The interest of the present study is to analyze to what extent a penalty clause that was provided in a contract that was unilaterally terminated or rescinded before its term may survive or remain applicable, as the contract is no longer in force. Moreover, given that according to the provisions in force, the penalty clause can be amended by a court - the penalty clause may be provided, in accordance to the parties' agreement for different reasons, such as the non-execution of the contract or the non-compliance to the obligations, it is interesting to note how this contractual provision may survive a contract that is no longer in force, in the form provided by the parties in their initial agreement.

In the present study, we aim to firstly analyze the current provisions in force in Romania, as well as overlook slightly the current provisions on the penalty clauses throughout different legislations. Secondly, we shall analyze the applicability of the penalty clause under the current Romanian regulations, as well as its integrity in a contract and last, we shall analyze the efficiency of the penalty clause and its ability to fully cover the prejudice of a creditor. 


\section{Regulation of the penalty clause}

The penalty clause is provided for in the Romanian civil Code in articles 1538-1543. It is regulated for two specific purposes, the first being in order to cover possible damages to the creditor made by the inexecution of the contract "The penalty clause is that by which the parties stipulate that the debtor is obliged to a certain performance in case of his inexecution of the principal obligation", and the second for the inexecution of the main obligation in due time or in the determined location "The creditor can't request the execution in nature of the principal obligation, as well as the payment of the penalty, apart from the case when the penalty was stipulated for the inexecution of the obligations in due time or in the determined place. In the latter case, the creditor can request both the execution of the main obligation, as well as the penalty, if he doesn't renounce his right or if he doesn't accept, without reserves, the execution of the obligation."

In accordance to doctrine, the penalty clause is an agreement of will, consecrated into a written contract, by which the parties determine the form, the levels and the modalities of engaging a legal contractual liability. By stipulating a penalty clause, the parties evaluate in advance the extent of the prejudice caused to the creditor by the nonexecution, inadequate execution or delayed execution of the obligations by the debtor (Urs et al., 2018, p.665). As previously shown, a penalty clause may also be provided for in case of the termination of a contract, be it with instant or successive execution.

Scholars have shown that penalty clauses provided for delay in the execution of an obligation have the legal nature of conventional moratorium interests, whereas penalty clauses provided for the inexecution of an obligation have the legal nature of compensatory damages. We stress out that the penalty clause can provide for a payment of a sum of money (that can be calculated as a percentage or as a flat-rate sum) or for another obligation, such as giving another good or supplying a service.

According to the regulation in force, we can point out the main characteristic of the penalty clause: first, it must be provided for in a written agreement between the parties, as such should fulfil all the conditions for the validity of the contract and can't be drafted on an invoice, as the latter is a unilateral manifest of will from the party issuing the invoice, and thus can't produce legal effects (High Court of Cassation and Justice, commercial division, decision nr. 1090 of 21 February 2001). Second, it is a pre-evaluation of the foreseeable prejudice of one of the parties at the moment of the conclusion of the contract, and as such there is no burden of proof of the extent of the prejudice by the creditor. However, one must note that even though the creditor has no obligation to prove the extent of the prejudice, he must prove the culpable inexecution of the debtor. Third, it must be stressed out the penalty is an accessory to the main obligation - thus, the penalty clause will be null and void if the main contract is null, applying the principle of accesorium sequitur principale; the penalty clause however can be declared null independently from the contract in which it was provided. Forth, it must be noted that the penalty clause can't be requested in the same time as the execution of the main obligation; as such, the creditor can choose between the payment of the penalty or the execution of the obligation, without the possibility to cumulate the two, unless the penalty was provided for the delay in execution. If the creditor could effectively ask for both the penalty clause and the execution of the main obligation, it would imply for the recovery of the same prejudice twice, and as such would lead to an enrichment without just cause. Fifth, the penalty clause will remain applicable if "there is a convention by which the creditor is entitled, in case of the termination or rescission of the contract through the fault of the debtor, to keep the partial payment made by the latter.", as per the provisions of article 1538 paragraph 5 of the civil Code. As such, the penalty clause that is a contractual clause, will survive the termination or rescission 
of the contract, if it concerns the inexecution of obligations or their inappropriate execution (Urs et al., 2018, p.666). Last, doctrine has pointed out the penalty clause should be provided for in the interest of both parties, in order to avoid its qualification as an abusive clause (Tomescu, 2015 , p. 347). Scholars have long debated if the penalty clause will be declared abusive or will be reduced by the court, and as such, we shall dedicate the last part of this study to this topic.

In international law, the approach is different - common law clearly makes a distinction between liquidated damages, used for compensatory purposes and penalty clauses, used to deter the breach. As such, the liquidated damages clause represents a genuine pre-estimate of damages, whether actual (or recoverable) loss amounts to more or less than the sum stipulated; the penalty clause is stipulated as in terrorem of the offending party (Miller, 2004, p. 80). Doctrine has ruled that the general rule under the common law is that a payment clause is only enforceable when it functions as a liquidated damages clause (Vitkus, 2013, p. 154).

However, recovering the penalty is not as easy as qualifying the clause in the contract either way, as one must pay attention to the scope of the penalty. There is a penalty when the stipulator pursues to impose on the one taking on the obligation an excessive sanction in regards to the just defense of his interest, a true pecuniary punishment. Such punitive intention seems unworthy of protection to the English judges who, in the equity jurisdiction, have refused to recognize pacts designed in terrorem, meaning with the scope to intimidate the debtor. The stipulated penalty shall be null. If on the contrary the penalty clause only has the aim to preventively determine the value of damages to be compensated (genuine pre-estimation of damages, liquidated damages), the clause is valid and by consequence shall produce the legal effect of limiting the damages: it results that the faulty debtor shall only be bound to pay the amount fixed in the clause. The excessive amount fixed by the sanction, in regards to the value of the anticipated damage at the moment of the conclusion of the contract is decisive for the nullity, as is the validity of the clause if the parties have agreed to a lesser amount than the foreseeable damage (Tullio, 1970, pp. 305-306).

Doctrine has long pointed out the differences between the efficiency model adopted by the civil law jurisdictions and the equity adopted by the common law. In the latter, its evolution has led to the conclusion that all penalties should in principle considered in terrorem. Courts and not individuals, should decide the proper manner in which to enforce contractual obligations, and should the judge decide not to grant it, the only available alternative remain damages, as insurance for idiosyncratic value is not available (Mattei, 1995, p.433). As in present, the civil law jurisdictions also allow the reduction of penalty clauses, one must note that one of the main differences between the systems is the moment in which the courts must analyze the amount of the penalty; as such, civil law systems admit the reduction of the penalty when it was apparently not unreasonable at the moment of stipulating the contract but appears unreasonable at the moment if its enforcement. Common law, by contrast, in looking for the intent to punish in order to forbid it, voids the clause when the amount appears excessive (compared to estimated damages) at the moment of the contract although it does not at the moment of enforcement (Mattei, 1995, p. 442). However, probably the most important difference between the two legal systems is that when the penalties are impossible to evaluate, such as per instance non-pecuniary damages, the civil law jurisdictions allow the penalties provided by the parties to stand. This makes all the difference when the parties are unable to quantify the damages, for instance because of the personal importance they take into the correct and complete performance of the obligation (moral, aesthetic, personal). 


\section{Applicability of the penalty clause}

In the civil law system, the penalty clause has the main following functions: punitive, as it seeks to sanction the non-compliance of the debtor to the contractual obligations, restorative, as it seeks to repair the prejudice of the creditor suffered by the lack of execution or inadequate execution of the obligation, assessment, as most authors consider that the penalty clause is a modality of assessing the prejudice suffered by the creditor, and guaranteeing as the penalty clause represents a means of guaranteeing the execution of the obligation available to the debtor (Tomescu, 2015, pp.347-348).

Regardless of the function of the penalty clause, we consider that its application must be corroborated with that of the application of the principle of good faith, that should be applied throughout the contract, from the negotiation phase until the termination, by any cause of the contract, as well as that of the lawful, just and full reparation of the prejudice caused to the debtor. The penalty provided should be sufficient to cover the possible losses provided by the parties at the conclusion of the contract, however should not be overvalued, as this might lead to an unlawful enrichment of the creditor.

As its main function is to repair the prejudice caused by the inexecution or by the wrongful execution by the debtor, the Romanian legislator has also regulated cases in which the penalty clauses can be reduced in order to avoid an abuse of the parties. As such, the penalty clause can be reduced if "the main obligation was executed in part and this execution has profited the creditor" or "the penalty is manifestly excessive compared to the prejudice that could have been foreseen by the parties at the conclusion of the contract." (article 1541 paragraph 1 of the civil Code). It should be underlined that these cases are an exception to the rule: on the basis of the principle of the binding force of the contracts, the parties are obliged to what they have agreed and as such the amount of the penalties provided couldn't be raised or diminished. As such, courts can't intervene and modify the amount of the penalty, unless one of the two above cases occur.

By the principle of mutability of the penalty clause, we understand the possibility of the judge to intervene by modifying the quantum of the penalty clause, in terms of reducing it, when it is excessive, or increasing it, when it is derisory (Pop, 2011, p. 12). Of the main questions that one has to ask when applying this principle are: when do courts have the possibility to reduce or increase the value of the penalty, in other words can this modification of the contract take place $e x$ officio, or does the judge need a request from one of the parties in order to intervene; this entails another critical issue: if the judge intervenes and assesses that the clause in "excessive", does he have the faculty or the obligation to modify it? Another important question is that pertaining to the evaluation of the clause and, eventually, its modification - by what standards is a clause to be qualified as "excessive" and how will it be modified?

We concur with the opinion expressed in doctrine, on the topic of the possibility of the courts to invoke ex officio the excessive character of the penalty: first, it should be noted that in order to answer this question, we should analyze especially the provisions of the Code of civil procedure, and not necessarily the provisions of the material civil law, and as such, it would appear that the courts can reduce the manifestly excessive penalty as opposed to the prejudice that was foreseeable by the parties at the conclusion of the contract only if the petition of the action comprises such a demand (Dumitru-Nica, 2014, p. 51).

As for the possibility to reduce the penalties comprised in the agreement of the parties, one must take into account at first the main reason that leads to the decrease of the amounts provided. In regards to the first case of reducing the penalty clause, meaning that the main obligation was executed and it profited to the creditor, doctrine has established that the limits of the implication 
of the courts is that of establishing the quantum in which the main obligation was executed and if this execution profited to the creditor (Adam, 2011, p. 715).

The second possibility for the court to reduce the quantum of the penalty is that the latter is "manifestly excessive" compared to the prejudice that could have been foreseen by the parties at the moment of the conclusion of the contract; one must bear in mind that the penalty clause is specifically provided in order to exonerate the creditor from having to prove any type of prejudice and as such, the penalty must be considered as opposed to the foreseeable prejudice at the moment of the conclusion of the contract, and not the prejudice effectively suffered by the creditor (Ungureanu et al., 2014, p. 1736). When calculating the prejudice, one must include the damage effectively suffered (damnum emergens) as well as the unfulfilled benefice (lucrum cessans) (Urs et all., 2018, p. 665). The civil Code also provides that the reduced penalty must remain superior to the main obligation. Doctrine has pointed out that the term "manifestly excessive" must be interpreted in the sense that it not only provides for an excessive penalty, but one so excessive, that evidently the judge will not need further verifications in order to assert this aspect (Oglindă, 2012, p. 491).

Doctrine has risen yet another important topic: when speaking about the excessive character of the penalties, one should first consider why the amount of the penalties is so high: either because of the percent of the penalty, or on the contrary because of the passivity of the debtor, who, in case the penalties were provided for the inexecution of an obligation on due date, as a percentage of the total amount, per day/week/month of delay, failed to fulfil his obligation. As such, jurisprudence as well as doctrine have ruled that it is inequitable to reduce the quantum of a penalty if the quantum is high as a result of the long number of days in which the debtor failed to fulfil his obligation, and not due to the percentage established by the parties (Ludușan, 2018, p. 57).

Also, jurisprudence and doctrine have ruled that according to the specific of the contract and the role of the penalty, the penalty clause can equal to the price of the contract - such clause may exist within a mandate contract, as to not allow the grantor to revoke abusively the mandate (see Ludușan, 2018, p. 59 on the penalty clause and Stoican, 2016, on the mandate contract). We consider that such can also be the case when speaking about long term contracts, when one of the parties makes a lot of investments pertaining to undertaking a contact - as such, when one party needs to make investments in their company in order to perform completely and fully a service contract, a penalty that would cover part of the contract's value would be justified.

We consider a real legal issue is provided for a penalty clause stipulated in the contract, where the existence of a prejudice is doubtful, either by the creditor's actions to mitigate the damages of the inexecution or of the wrongful execution, or because the damage can't be quantified by the court of law (for instance, because it is considered to be a personal non-pecuniary damage). In such cases, we consider that the courts can't intervene as to modify the extent of the penalties, even if they are excessive. However, doctrine has pointed out that the practice of arbitration courts in cases where the limitation of the penalty clause was not directly applicable, should be to reduce the amount of the penalty based on the practice of abuse of rights (Angheni, 2016, p. 18).

Another very important topic that one must take into account is the protection of the personal date of the debtor - as such, given the European regulations in force, the creditor must take special notice into informing the debtor upon the collection of the debt, including the penalty clause. This issue is particularly raised between banks and their clients, in particular when the debt is assigned to a debt collection company. The latter has the obligation to protect the confidentiality and ensure the technical al legal certainty of all information obtained from the contracting parties 
regarding the negotiation, execution and performance of the contract (Mănescu, 2018, p. 798, see also Chirică, 2017).

Given these considerations on the possibility to amend a contractual clause drafted by the parties, one must ask what can be the efficiency of a penalty clause? The inconsistent practice provided by the courts, there is a level of uncertainty for the parties when subjecting their initial contract to review.

\section{Efficiency of penalty clauses}

Following the changes occurred in the legislation in 2011, the Civil Code provides in articles 1550-1552, that rescission can also intervene on a basis of unilateral declaration of rescission issued by the entitled party, under a simple reserve of an enforcement notice under any of the conditions that follow: (i) when the parties have so agreed; (ii) when the debtor has legally been put in delay; (iii) when the debtor has failed to execute on formal notice, within the deadline by delaying. The old provisions provided only for judicial recession for the wrongful non-performance of the debtor (Bărbulescu, 2015, p. 375).

As such, the parties can provide for a commissoria lex pact, that allows either parties to stipulate a clause clearly determining the conditions that will lead to the rescission or the termination of the contract (see Dumitru, 2020). The question that remains is if the penalty clauses will survive the rescission or the termination of the contract, and if they can be cumulated either with interests or damages.

The main rule developed by scholars and courts alike is that a penalty can't be cumulated with another remedy to the contract if they pursue the same function, in other words, if they aim to repair the same prejudice caused to the creditor - either the delayed execution or the inexecution of an obligation.

In regards to penalties for delayed execution, they are usually drafted in progressive percentages shares from the due date until de moment of execution of the obligation, either in kind, or until the execution in nature is no longer possible, according to legal or conventional provisions (Angheni, 2019, p. 439). The civil Code clearly provides in article 1539 that such penalties can be cumulated with the execution in kind, and by corroborating this article with article 1538, paragraph 2 and 3, we understand that the creditor may choose whether he will pursue a penalty clause for the inexecution of the main obligation or the execution in kind, as the debtor can't liberate himself from the obligation providing the damages stipulated by the parties. However, jurisprudence has ruled the penalties provided for a delayed execution can't be cumulated with legal or conventional interest, as they both fulfil the same function, a pre-determined quantification of the prejudice caused by the delayed execution (Ungureanu, 2014, p. 1741).

The real question remains if the penalty can survive the contract in case of a rescission or termination of the latter - courts and scholars (see Angheni, 2019, pp. 440, 441) have ruled that in order for the penalty to survive the contract, there must be a commissory lex provided into the contract - as such, if the penalties are provided for the delay of the execution or for the wrongful execution, they may be cumulated with the rescission or the termination of the contract.

When taking into consideration the possibility to cumulate penalties for the inexecution of the obligation with damages for the inexecution, normally this solution is impossible without the existence of a clause comprised in the contract that provides for the addition of damages to the penalty (see Ludușan, 2018, pp. 58-59; Urs et all., 2018, pp. 666). There are arguments that support both possibilities: if we were to dismiss the possibility of the creditor to obtain supplementary damages, it would actually be based on the nature of the penalty clause, a pre-evaluation for 
possible damages, made by the parties. If we were to allow this addition of damages, we would have to consider article 1531 that clearly stipulates that the creditor has the right to the full redress of the prejudice which he has suffered by the inexecution. If we were to allow the accumulation of the penalties and damages, the creditor will have to prove the extent of the prejudice, as well as the ratio between the juridical cause of the penalties and those of the damages, as well as meet the conditions provided for the expectancy of the prejudice: certain, direct, predictable and that it isn't covered by the penalties (Angheni, 2019, p. 443). The main differences between asking for penalties or for damages is that the first needs no proving and mainly the moment when the prejudice is evaluated.

The penalties for the inexecution can never be cumulated with the execution in kind of the main obligation, as per the legal interdiction comprised in article 1539 of the civil Code. Applying the same reasoning, we consider that penalties for the delayed execution can never be cumulated with interests, be they conventional or legal, as they would provide for the reparation of the same prejudice twice. Of course, there is no hierarchy upon the means available to the creditor in order to recover the prejudice, the latter being able to use any of the means stated above.

The civil Code distinguishes between the obligation to do something and the obligation to pay a sum of money. In the first case, the creditor always has the possibility to prove a greater prejudice than the one calculated by applying the legal interest either by a penalty or by requesting additional damages. When the main obligation is that of a payment of a sum of money, the creditor may only request additional damages if the moratory interests are lower than the legal interest. This case is however not applicable in contracts between professionals, or professionals and contracting authorities, as this would constitute grounds for an unfair clause, in accordance to the provisions of Law 72/2013.

Pertaining to the addition of penalty clauses with another type of compensation, the last issue we want to stress is the possibility to index the penalty with the inflation rate. The High Court of Cassation and Justice ruled on numerous occasions that the juridical nature of the interest is different than the juridical nature of the actualization of the obligation with the index rate: interests represent moratory damages for the inexecution of the obligation to pay, whereas indexing the obligation with the inflation rate leads to the real value of the pecuniary obligation at the moment of payment (compensatory damages). As such, the HCCJ concluded adding the two is admissible as it would not lead to a double reparation, and thus an unjust enrichment of the creditor (decision no. 304/2009; decision no. 722/2010; decision no. 4426/2013; decision no. 2061/1025).

\section{Conclusion}

In this paper, we first analyzed the regulation of the penalty clause under the Romanian regulation by comparison with common law systems and found that under our regulation the penalty clauses are always accepted, as they have several functions among which to encourage the debtor to execute his obligations fully, correctly and in due time, as well as insure the creditor for his potential losses. Next, we saw that the penalty clauses can exceptionally be reduced by the courts of law either if the debtor has partly executed his obligation and thus has profited the creditor, or because the penalty provided by the parties is manifestly excessive in regards to what the parties could have foreseen at the conclusion of the contract. In the last part, we aimed to analyze the efficiency of the penalty clauses, seeing how they could be reduced or risen by the courts: we have thus seen that penalty clauses can be efficient as they can be cumulated with other types of contractual remedies, such as interest (legal or conventional) or with the execution of the obligation in kind (when possible). Also, we have seen that it is a long-standing practice for 
the HCCJ to allow the cumul of penalties with the inflation rate, keeping in mind that the creditor has the right to a full reimbursement of his prejudice, as well as the fact that the full recovery of the prejudice must not lead to a compensation beyond the latter.

The penalty clauses have also been used in contracts between professionals or professionals and public authorities. As mentioned before, if a penalty clause is provided for less than the legal interest, it will be qualified as an abusive clause. Recently, an issue pertaining to the undergoing of a public service contact has opposed a local public authority to a private professional. Doctrine has expressed an opinion that administrative contracts have a mixt juridical nature and underlines the difference between an unfair (abusive) clause and the abusive pursuit of a contractual clause by one of the parties - as such, on the matter of delegation of the administration of public services, by which there are provisions pertaining to the reparation of the prejudice caused to the operator by the user, under the provisions of the contract, the operator might be entitled to damages, even though, in practice, he effectively suffered no prejudice, context in which we would be in the case of an abusive pursuit of a contractual clause (Ludușan, 2014, pp. 164-167). We underline that when talking about penalty clauses, the creditor has no obligation to prove the prejudice suffered by the inexecution or by the rescission or termination of the contract, as long as the penalty clause is valid. It can be subjected to mutability by the courts and thus reduced in value if it is deemed excessive, however its integrity can't be subjected to debate. Furthermore, if we take into consideration the mixt nature of the contract, we have to stress the possibility of both parties to negotiate the contract and determine the nature and extent of clauses. Also, in this type of contract, usually the contracting authority has a top position as it is the one choosing among several offers provided by different professionals. Thus, in our opinion, there would be no legal argument to not apply a penalty clause when it is provided in a contract between public and private actors, in contracts related to private matters, as it would go against the provisions of the civil Code.

\section{References}

Adam, I. (2011). Drept civil. Obligațiile. Contractul. Bucharest. C.H. Beck Publishing House.

Angheni, S. (2016). Étude sur le mecanisme de fonctionnement de la clause pénale et particulièrement sur son application dans le cas de la resolution ou de la résiliation du contrat. Titu Maiorescu Law review, XV/2016, 9-22.

Angheni, S. (2019). Drept comercial: tratat. Bucharest. C.H. Beck Publishing House.

Baias, F.A., Chelaru, E., Constantinovici, R., Macovei, I., coord.: Ungureanu, D. (2014). Noul Cod civil. Comentariu pe articole. $2^{\text {nd }}$ edition, Bucharest. C.H. Beck Publishing House.

Bărbulescu, O. (2015). The utility of the rescission clause in the settlement of disputes arising from international trade contracts. Bulletin of Transilvania University of Braşov. Series V: Economic Sciences, Vol. 8 (57) no. 2, 373-378.

Chirică, S. (2017). The main novelties and implications of the new general data protection regulation, Perspectives of business law journal, 6(1), 159-176.

Dumitru, O.I. (2020). Contract law. Lecture notes, Bucharest, ASE Publishing House.

Dumitru-Nica, M. (2014). Reducerea clauzei penale vădit excesive - „la cerere” sau și „din oficiu”, Law review, 08/2014, 43-52.

Ludușan, F. (2014). Clauza penală. Conexiuni și diferențe în raport cu alte clauze contractuale, Law Review, 4/2014, 94-119.

Ludușan, F. (2014). Discuții cu referire la clauzele abuzive în contractele negociate, cu privire specială asupra clauzei penale abusive, Law review, 06/2014, 155-167. 
Luduşan, F. (2018). Aspecte teoretice și jurisprudențiale referitoare la reductibilitatea clauzei penale în Codul civil, Law review, 02/2018, 51-66.

Mattei, U. (1995). The comparative law and economics of penalty clauses in contracts, The American Journal of Comparative Law, 43/1995, 427-444.

Mănescu, D.M. (2018). Recovery of claims in the GDPR (General Data Protection Regulation) era, Juridical Tribune, 8(3), 789-800.

PICBE |

Miller, L. (2004). Penalty clauses in England and France: a comparative study, International and comparative law Quarterly, 79-106.

Oglindă, B. (2012). Dreptul afacerilor. Bucharest, Universul Juridic Publishing House.

Pop, L. (2011). Reglementarea clauzei penale în textele noului Cod civil, Law review, 8/2011, 11-26.

Stoican, A. (2016). Contractele de intermediere: contractul de mandat, contractul de comision, contractul de consignaţie, contractul de expediţie, contractul de agenţie, contractul de intermediere, Bucharest, Universul Juridic Publishing House.

Tomescu, R.A. (2015). Contractual liability. Rescission and termination of contract, penalties, interests, damages, penal clause, International conference Education and Creativity for a Knowledge based Society - Law, IX/2015, 345-349.

Tullio, S. (1970). Clause pénale et dommages ultérieurs en droit comparé. Revue internationale de droit comparé, 22(2), avril/juin, 299-311.

Urs, I.R., Dutu M. (coord.), et al. (2018). Enciclopedia juridică română (vol. 1), Bucharest, Romanian Academy Publishing House, Universul Juridic Publishing House.

Vitkus, S. (2013). Penalty clauses within different legal systems, Social transformations in contemporary society, 2013(1), 153-162.

DOI: 10.2478/picbe-2021-0082, pp. 893-902, ISSN 2558-9652|

Proceedings of the $15^{\text {th }}$ International Conference on Business Excellence 2021 